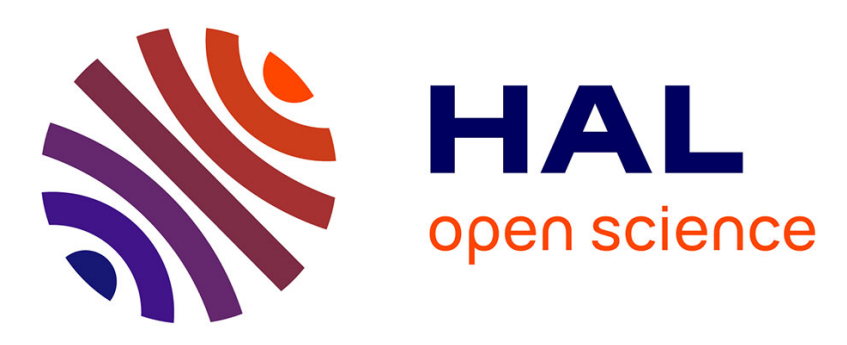

\title{
Chemical shrinkage of cement pastes and mortars at very early age: effect of limestone filler and granular inclusions
}

Marwen Bouasker, Pierre Mounanga, Ph Turcry, Ahmed Loukili, Abdelhafid Khelidj

\section{To cite this version:}

Marwen Bouasker, Pierre Mounanga, Ph Turcry, Ahmed Loukili, Abdelhafid Khelidj. Chemical shrinkage of cement pastes and mortars at very early age: effect of limestone filler and granular inclusions. Cement and Concrete Composites, 2008, 30 (1), pp.13-22. 10.1016/j.cemconcomp.2007.06.004 . hal-01005858

\section{HAL Id: hal-01005858 \\ https://hal.science/hal-01005858}

Submitted on 14 Oct 2017

HAL is a multi-disciplinary open access archive for the deposit and dissemination of scientific research documents, whether they are published or not. The documents may come from teaching and research institutions in France or abroad, or from public or private research centers.
L'archive ouverte pluridisciplinaire HAL, est destinée au dépôt et à la diffusion de documents scientifiques de niveau recherche, publiés ou non, émanant des établissements d'enseignement et de recherche français ou étrangers, des laboratoires publics ou privés. 


\title{
Chemical shrinkage of cement pastes and mortars at very early age: Effect of limestone filler and granular inclusions
}

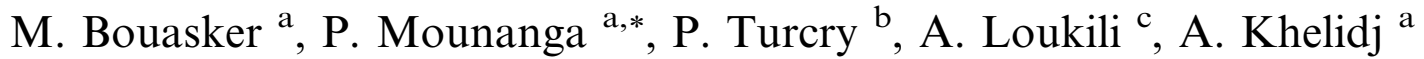 \\ ${ }^{a}$ GeM, UMR CNRS 6183 - Research Institute on Civil Engineering and Mechanics, IUT Saint-Nazaire, 58 rue Michel Ange, BP 420, F-44606 \\ Saint-Nazaire cedex, France \\ ${ }^{\mathrm{b}}$ LEPTAB, University of la Rochelle, Avenue Michel Crépeau, F-17042 La Rochelle cedex 01, France \\ ${ }^{\mathrm{c}}$ GeM, UMR CNRS 6183 - Research Institute on Civil Engineering and Mechanics, Ecole Centrale de Nantes, 1 rue de la Noë, BP 92101 , \\ F-44321 Nantes cedex, France
}

This article presents a study on the influence of limestone filler and granular inclusions on the chemical shrinkage of cementitious matrices at very early age $(\leqslant 24 \mathrm{~h})$. Measurements of chemical shrinkage and hydration degree are carried out on cement pastes and mortars. During this study, two cement types (CEM 1 and CEM 2), two water-to-cement ratios (W/C $=0.30$ and 0.40$)$ and three substitution rates of cement by limestone filler $(\mathrm{LF} / \mathrm{C}=0 ; 0.25$ and 0.67$)$ are used. The effects of aggregate shape (glass beads and natural sand), aggregate-to-cement mass ratio $(\mathrm{A} / \mathrm{C}=0.5$ and 1$)$ and particle size distribution $(D=1$ and $2 \mathrm{~mm})$ on the chemical shrinkage and the hydration rate are quantified. The results obtained show that limestone filler causes an acceleration of both Le Chatelier's contraction and hydration process since the very first hours of hydration. In addition, the chemical shrinkage amplitude is not significantly influenced by the presence of aggregates. Finally, the presence of limestone filler and granular inclusions does not cause significant modification of the quasi-linear relation observed at early age between the chemical shrinkage and the hydration degree of the cementitious matrices.

Keywords: Chemical shrinkage; Cement paste; Mortar; Early age; Filler limestone; Hydration

\section{Introduction and context of the study}

Early age shrinkage of cementitious matrices is the result of several complex physico-chemical phenomena. Those phenomena are related to the hydration reactions between cement and water and to the progressive hardening of the mineral skeleton. It is generally considered that at mature age, in autogenous conditions, the autodesiccation of the material, i.e. the progressive desaturation of its porosity, generates compressive forces high enough to cause volume changes called autogenous shrinkage. These forces are par-

\footnotetext{
${ }^{*}$ Corresponding author. Tel.: +332401786 04; fax: +33240178160. E-mail address: pierre.mounanga@univ-nantes.fr (P. Mounanga).
}

ticularly intense in cement-based matrices with low W/C ratio [1].

At very early age and during setting, two phenomena are directly responsible for the shrinkage of material in sealed conditions: capillary depression in the porous space and Le Chatelier's contraction. Le Chatelier's contraction is explained by the density difference between hydrates on the one hand and cement and water on the other hand. At complete hydration, this contraction can represent approximately $10 \%$ of the initial volume of the material.

The material rarely exhibits such a high deformation because the progressive hardening resists to this chemical shrinkage. However at very early age and before setting, when the cementitious matrix does not reach its full maturity and resistance, Le Chatelier's contraction represents a significant part of the deformations. The comprehension of 
the autogenous shrinkage mechanism at the first stage of hydration thus requires to better quantify the influence of both mix and curing parameters on the amplitude and the kinetics of Le Chatelier's contraction.

This study, in the following of a previous research work on the influence of $\mathrm{W} / \mathrm{C}$ ratio and curing temperature on the chemical shrinkage of cement pastes [2], focuses on the effect of limestone filler and granular inclusions on Le Chatelier's contraction of mortars and cement pastes. These two mineral components can be regarded as chemically inert at early age. However, they have an indirect action on the hydration and the microstructure development and thus on the deformations of the cementitious matrices. The limestone filler can particularly play the role of nucleation and growth sites for the hydrates. Several studies revealed that the hydration process of $\mathrm{C}_{3} \mathrm{~S}$ and $\mathrm{C}_{3} \mathrm{~A}$, two major components of Portland cements, was affected by the presence of limestone filler: the hydration kinetics is accelerated, the hydration reactions release more heat and the hydrate composition is modified [3-6], particularly beyond one day of hydration [7-9]. Aggregates induce a better dispersion of the cement grain clusters during mixing and are usually at the origin of a porous interface zone with the binding phase [10-12].

In this work, two cement types, CEM 1 and CEM 2, are investigated. The filler limestone incorporated is largely used for the making of self-compacting concrete [13]. Granular inclusions are of two origins: a natural siliceous river sand and glass beads, in order to study the influence of the inclusion shape on the chemical shrinkage of mortars. The period of investigation is limited to the first $24 \mathrm{~h}$ of hydration. Indeed, beyond a few hours, the main mechanism of deformation becomes the autodesiccation of the matrix and the volume changes result from the competition between the gain of stiffness of the solid skeleton and the mechanical stresses generated by the progressive desaturation of the capillary space.

The article firstly analyzes the previous research works published on the evolution of the chemical shrinkage of cementitious systems. Then, the studied materials and the testing methods used in the present research task are detailed. The results obtained are discussed by comparing parallel measurements of chemical shrinkage and hydration degree.

\section{Bibliographical analysis}

\subsection{Chemical shrinkage and autogenous shrinkage}

At very early age, the autogenous shrinkage is a physicochemical phenomenon, coupled to mechanical capillary actions due to the consumption of pore water by the cement hydration. During the first hours of hydration (from the water-cement contact up to the beginning of the setting), the capillary actions can be regarded as negligible. During this phase, the autogenous shrinkage mainly corresponds to Le Chatelier's contraction (Fig. 1).

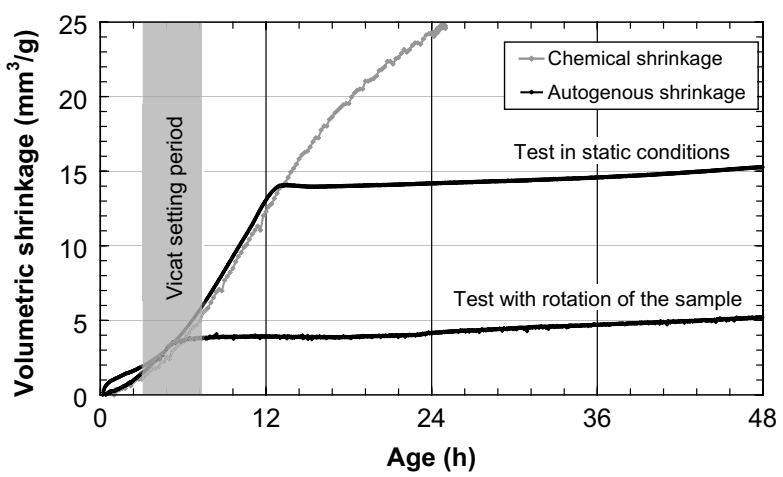

Fig. 1. Chemical and volumetric autogenous shrinkage of a CEM 1 cement paste with $\mathrm{W} / \mathrm{C}=0.40$. Inspired by Bouasker et al. [42].

Le Chatelier's contraction is measured by ensuring a constant water saturation of the porous space of the material. On the basis of this principle, many experimental studies [2,14-40] have been carried out and some analytical and numerical models have been proposed $[2,34,41]$ in order to determine the chemical shrinkage of cement pastes.

\subsection{Measurement methods}

Justnes et al. [24] listed, in 2000, three principal measurement methods of Le Chatelier's contraction: dilatometry, pycnometry and gravimetry. The principles of the three methods are recalled in Fig. 2.

Among these test methods, the most widely used remains the dilatometry. Developed by the inventor of Le Chatelier's contraction, it was sophisticated by Powers [43] and by Buil [44]: Buil proposed for example an automatic follow-up of the water level in the capillary tube. Many researchers [19-29,31,32,37-39] have used the dilatometry to study the influence of the cement composition, the $\mathrm{W} / \mathrm{C}$ ratio, the presence of pozzolanic additions and polymer additives on the evolution of chemical shrinkage. This method is the object of a measurement protocol defined by the Japanese Concrete Institute (JCI) in 1999 [45].

In 1999, Garcia-Boivin [31] showed theoretically and experimentally the equivalence of the results obtained by dilatometry and gravimetry. The gravimetry, which is used in the present study, has been initiated by Rey [46] and improved by Geiker and Knudsen [14-16,47], Paulini $[17,18]$ and Garcia-Boivin [30,31]. It allows, with a simple experimental device (see Fig. 2), to record automatic and continuous measurements of chemical shrinkage.

\section{Experimental program}

\subsection{Materials}

\subsubsection{Cements}

Two commercial Portland cement types are used during this study: a CEM 1 cement (Saint-Pierre La Cour) and a 


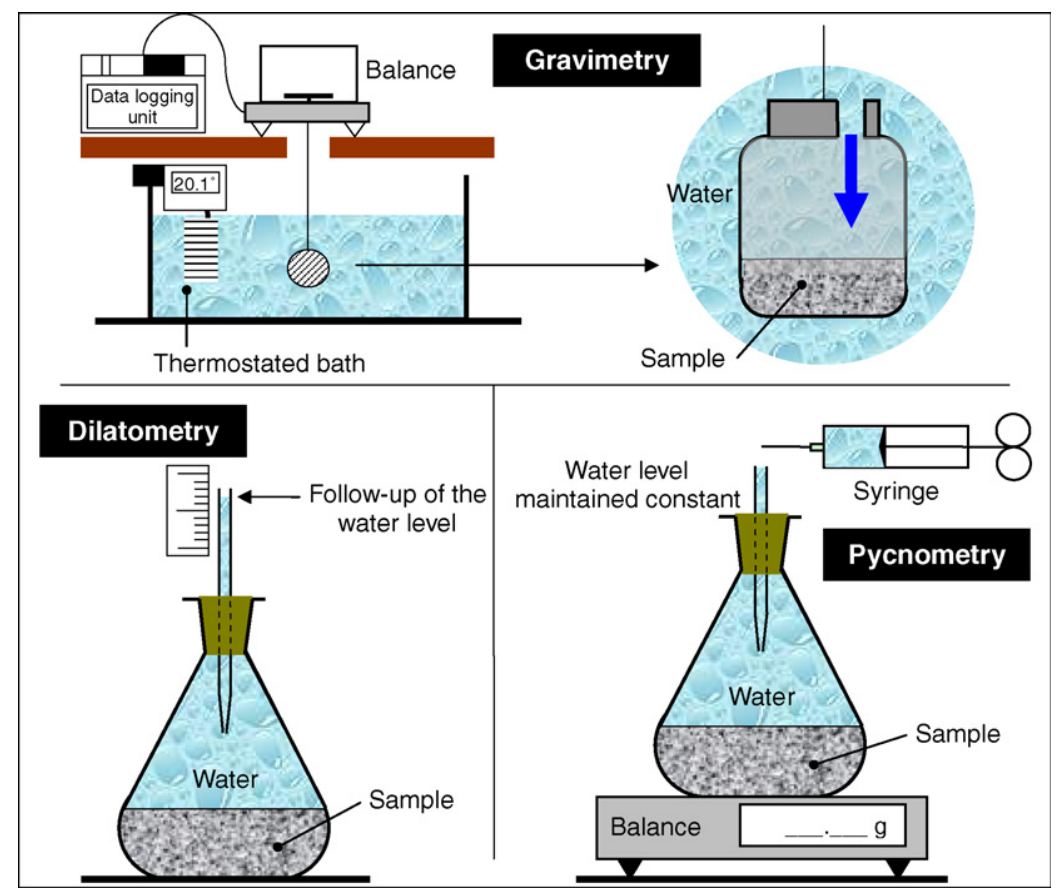

Fig. 2. Chemical shrinkage measurement methods.

CEM 2 one (Airvault). Note that for the CEM 1 cement, two batches, manufactured in the same factory but at different times, have been used: the CEM 1-a cement for the study on filler effect and the CEM 1-b cement for investigating the influence of granular inclusions. They have a similar particle size distribution (PSD) but slight differences in their Bogue's composition.

The composition and the Blaine specific surface of the cements and the mass fractions of the principal phases $\mathrm{C}_{3} \mathrm{~S}, \mathrm{C}_{2} \mathrm{~S}, \mathrm{C}_{3} \mathrm{~A}$ and $\mathrm{C}_{4} \mathrm{AF}$ are given in Table 1. Fig. 3 provides the PSD of the cements.

\subsubsection{Limestone filler}

The limestone filler comes from Erbray (France). Its carbonate content is $98.4 \%$. Its specific surface and bulk density are $3970 \mathrm{~cm}^{2} / \mathrm{g}$ and $2714 \mathrm{~kg} / \mathrm{m}^{3}$, respectively. Fig. 3 displays its PSD.

Table 1

Chemical composition of the cements used

\begin{tabular}{llll}
\hline $\begin{array}{l}\text { Composition } \\
\text { (mass percentage) }\end{array}$ & \multicolumn{2}{l}{ CEM I 52.5 N } & $\begin{array}{l}\text { CEM II/A-LL 42.5 R CE } \\
\text { CE CP2 NF }\end{array}$ \\
\cline { 2 - 3 } & CEM 1-a & CEM 1-b & CEM 2 NF \\
\hline Clinker & 97 & 92 \\
Limestone & 2 & 6 \\
Filler & 1 & 2 \\
Bogue's cement composition (mass percentage) \\
$\mathrm{C}_{3} \mathrm{~S}$ & 62.89 & 62.01 & 53.31 \\
$\mathrm{C}_{2} \mathrm{~S}$ & 9.12 & 11.13 & 17.69 \\
$\mathrm{C}_{3} \mathrm{~A}$ & 6.76 & 8.11 & 8.11 \\
$\mathrm{C}_{4} \mathrm{AF}$ & 9.54 & 8.45 & 8.45 \\
\hline
\end{tabular}

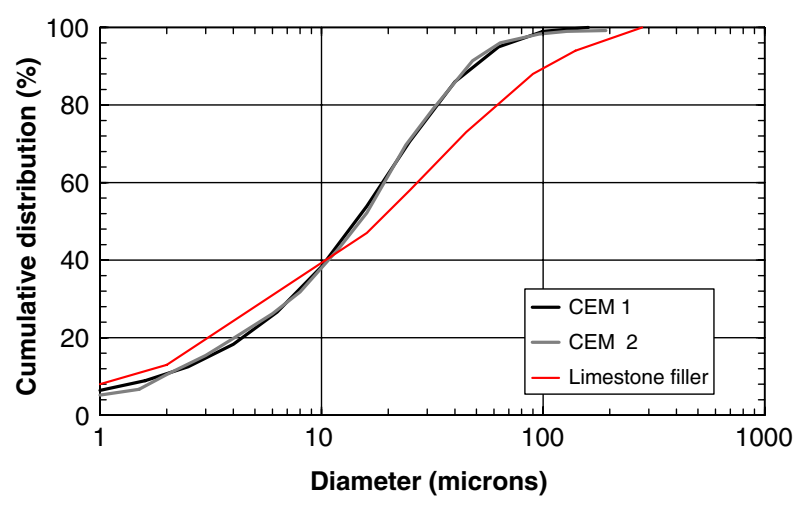

Fig. 3. Particle size distribution of cements and limestone filler.

\subsubsection{Natural and artificial granular inclusions}

The natural aggregate used is siliceous river sand. Before the mortar preparation, it was filtered with sieves of 1.25 and $0.80 \mathrm{~mm}$ (sand noted " $1 \mathrm{~mm}$ ") and sieves of 2.5 and $1.63 \mathrm{~mm}$ (sand noted " $2 \mathrm{~mm}$ "). The sand water content is $1.27 \%$. The artificial aggregates correspond to completely non-porous and dry glass beads with a diameter of $2 \mathrm{~mm}$.

\subsection{Preparation of the cement pastes and mortars}

The cement pastes and mortars are prepared by mixing the solid components with water, according to the procedures and mixing times detailed on Fig. 4. The 5 L-mixer used is in conformity with European standards (EN 1961). Finally, the different investigated mixtures are recapitulated in Table 2. 


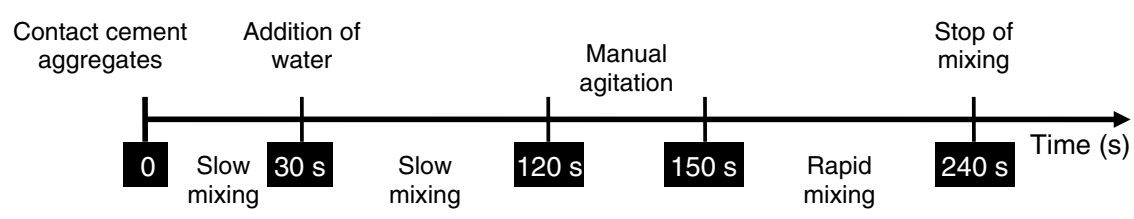

Fig. 4. Mixing procedure.

Table 2

Mass proportions of the cement-based systems

\begin{tabular}{|c|c|c|c|c|c|c|}
\hline \multirow[t]{2}{*}{ Nomenclature } & \multicolumn{6}{|c|}{ Mix parameters } \\
\hline & Cement type & $\mathrm{W} / \mathrm{C}$ & Aggregate type & $\mathrm{LF} / \mathrm{C}$ & $\mathrm{A} / \mathrm{C}$ & $\mathrm{W} /(\mathrm{C}+\mathrm{LF})$ \\
\hline CEM 1:CaCO3-1:0 & CEM 1-a & 0.40 & - & 0 & - & 0.40 \\
\hline CEM 1:CaCO3-0.8:0.2 & & & & 0.25 & & 0.32 \\
\hline CEM 2:CaCO3-1:0 & CEM 2 & & & 0 & & 0.40 \\
\hline CEM 2:CaCO3-0.8:0.2 & & & & 0.25 & & 0.32 \\
\hline CEM 2:CaCO3-0.6:0.4 & & & & 0.67 & & 0.24 \\
\hline Glass $(2 \mathrm{~mm}) \mathrm{W} / \mathrm{C}=0.3 \mathrm{~A} / \mathrm{C}=1$ & & 0.30 & Glass beads $(\varnothing 2 \mathrm{~mm})$ & & 1.00 & \\
\hline Sand $(2 \mathrm{~mm}) \mathrm{W} / \mathrm{C}=0.3 \mathrm{~A} / \mathrm{C}=0.5$ & & & Natural sand $(\varnothing 2 \mathrm{~mm})$ & & 0.50 & \\
\hline Glass $(2 \mathrm{~mm}) \mathrm{W} / \mathrm{C}=0.4 \mathrm{~A} / \mathrm{C}=0.5$ & & 0.40 & Glass beads ( $\varnothing 2 \mathrm{~mm})$ & & 0.50 & \\
\hline Glass $(2 \mathrm{~mm}) \mathrm{W} / \mathrm{C}=0.4 \mathrm{~A} / \mathrm{C}=1$ & & & & & 1.00 & \\
\hline Sand $(1 \mathrm{~mm}) \mathrm{W} / \mathrm{C}=0.4 \mathrm{~A} / \mathrm{C}=0.5$ & & & Natural sand $(\varnothing 1 \mathrm{~mm})$ & & 0.50 & \\
\hline Sand $(2 \mathrm{~mm}) \mathrm{W} / \mathrm{C}=0.4 \mathrm{~A} / \mathrm{C}=0.5$ & & & Natural sand $(\varnothing 2 \mathrm{~mm})$ & & 0.50 & \\
\hline
\end{tabular}

$\mathrm{C}$, cement; W, water; LF, limestone filler; A, aggregates.

\subsection{Test methods}

\subsubsection{Vicat setting time}

Initial and final setting times of cement pastes are determined at $20 \pm 1{ }^{\circ} \mathrm{C}$ according to the procedure described in the EN 196-1 European standards. The precision of the measurement is $\pm 10 \mathrm{~min}$. For each cement paste, three simultaneous Vicat tests are carried out to determine the average setting time.

\subsubsection{Chemically-bound water and hydration degree}

The hydration degree of the cementitious matrices is calculated from the measurement of the quantity of chemically-bound water $\left(W_{n}\right)$. In the case of the cement pastes, the amount of $W_{n}$, defined here as the mass loss recorded between 145 and $950{ }^{\circ} \mathrm{C}$, is determined by thermogravimetric analysis (TGA). The detailed test procedure can be found in $[2,40]$.

The TGA method is not easily applicable to mortar because of the very little volume of the crucible containing the sample. The amount of the chemically-bound water within the mortars is thus measured by loss on ignition (LOI). This testing method indeed makes it possible to study larger material samples. The various stages of the method are recapitulated in Table 3 .

The principal experimental parameters of TGA and LOI methods are finally summarized in Table 4 . For each studied mixture, two samples are tested in order to calculate the average hydration degree of the material.
Table 3

Stages of the loss of ignition (LOI) method

\begin{tabular}{ll}
\hline Stages & Time \\
\hline Sampling of $50 \pm 10 \mathrm{~g}$ of mortar & $10 \mathrm{~min}$ \\
Crushing of the sample & $10 \mathrm{~min}$ \\
Impregnation of the sample with methanol (to stop hydration) & $10 \mathrm{~min}$ \\
Drying at $145^{\circ} \mathrm{C}$ & $20 \mathrm{~h}$ \\
Placing in a desiccator & $15 \mathrm{~min}$ \\
Mass measurement (accuracy: $\pm 0.01 \mathrm{~g})$ & $2 \mathrm{~min}$ \\
Heating at $950^{\circ} \mathrm{C}$ & $4 \mathrm{~h}$ \\
Placing in a desiccator & $15 \mathrm{~min}$ \\
Mass measurement (accuracy: $\pm 0.01 \mathrm{~g})$ & $2 \mathrm{~min}$ \\
\hline
\end{tabular}

Table 4

Test parameters for the measurement of chemically-bound water

\begin{tabular}{lll}
\hline Parameters & \multicolumn{2}{l}{ Test methods } \\
\cline { 2 - 3 } & TGA & LOI \\
\hline $\begin{array}{l}\text { Mass of sample } \\
\text { Age of sample }\end{array}$ & $40-70 \mathrm{mg}$ & $15-20 \mathrm{~g}$ \\
Type of crucible & $3,6,9,24 \mathrm{~h}$ & $4,8,12,16,20,24 \mathrm{~h}$ \\
$\begin{array}{l}\text { Heating rate } \\
\text { Temperature range for the } \\
\text { calculation of } \mathrm{W}_{n}\end{array}$ & $\begin{array}{l}\text { Platinum } \\
10{ }^{\circ} \mathrm{C} / \mathrm{min}\end{array}$ & $\begin{array}{l}\text { Porcelain } \\
\text { Environment }\end{array}$ \\
$\begin{array}{lll}\text { Pre-treatment of the sample } & 145-950^{\circ} \mathrm{C} & 145-950^{\circ} \mathrm{C} \\
& \text { Nitrogen } & \text { Air (1 bar) } \\
& \text { None } & \text { (1) Crushing } \\
& & \text { (2) Impregnation } \\
\text { with methanol }\end{array}$ \\
\hline
\end{tabular}


Table 5

Test parameters for the measurement of Le Chatelier's contraction

\begin{tabular}{ll}
\hline Test parameters & Value \\
\hline Mass of sample & $20-30 \mathrm{~g}$ \\
Exchange surface area between sample and bath water & $20 \pm 1 \mathrm{~cm}^{2}$ \\
Thickness of sample & $9 \pm 1 \mathrm{~mm}$ \\
Liquid of immersion & Distilled water \\
Temperature of the liquid of immersion & $20 \pm 0.1^{\circ} \mathrm{C}$ \\
\hline
\end{tabular}

\subsubsection{Chemical shrinkage}

The chemical shrinkage is measured by gravimetry. The test procedure is detailed in [2]. Table 5 points out the main experimental parameters of the testing method. Each studied mixture is prepared and tested twice in order to determine the average curve of chemical shrinkage.

Several researchers $[15,31,48]$ were interested in quantifying the influence of bleeding and ponding fluid on the rate and amplitude of chemical shrinkage.

Geiker and Knudsen [15] measured the amount of bleeding water $2 \mathrm{~h}$ after the first water-cement contact and corrected the $\mathrm{W} / \mathrm{C}$ ratio of the cement pastes subjected to this bleeding. The higher difference of $\mathrm{W} / \mathrm{C}$ ratio before and after bleeding observed on cement pastes with $\mathrm{W} / \mathrm{C}=0.8$ was about $5 \%$. This difference was not significant for the pastes with $\mathrm{W} / \mathrm{C}=0.40$.

Sant et al. [48] tested various concentrations and compositions of the ponding fluid on the sample and recorded a difference in chemical shrinkage during the very first hours. Garcia-Boivin [31] carried out the same experiment with distilled water and water saturated with lime as the ponding fluid. By readjusting the shrinkage curves at $100 \mathrm{~min}$ after the first water-cement contact, she obtains almost superimposed evolutions of chemical shrinkage.

In the continuation of the present study, the liquid of immersion is distilled and deaerated water and no particular precaution is taken to remove the bleeding water of the cementitious matrices, considering their $\mathrm{W} / \mathrm{C}$ ratio $(\mathrm{W} /$ $\mathrm{C}=0.30$ and 0.40 ) and in accordance with Geiker and Knudsen's results [15].

\section{Results and discussion}

\subsection{Repeatability of the tests}

As previously indicated, each test is achieved twice for the measurement of the hydration degree and the chemical shrinkage and three times for the Vicat setting times. The maximum variations recorded between two tests carried

Table 6

Results of repeatability tests

\begin{tabular}{lll}
\hline Test methods & $\begin{array}{l}\text { Number of } \\
\text { repeatability tests }\end{array}$ & $\begin{array}{l}\text { Maximum variation } \\
\text { observed }\end{array}$ \\
\hline $\begin{array}{l}\text { Vicat setting time } \\
\text { Hydration degree (TGA } \\
\quad \text { or LOI) }\end{array}$ & 3 & $\pm 15 \mathrm{~min}$ \\
$\begin{array}{l}\text { Chemical shrinkage } \\
\text { P }\end{array}$ & 2 & $\pm 4 \%$ \\
\hline
\end{tabular}

out on the same mortar or cement paste formulation are given in Table 6. In the following of this article, each curve or value presented is an average result calculated with two or three test results.

\subsection{Effect of limestone filler}

\subsubsection{Hydration degree}

Figs. 5 and 6 present the evolution of the hydration degree of the various cement pastes. The presence of limestone filler is at the origin of an increase of hydration rate of the two cement types. This filler effect, already described in previous studies [3-9], is generally explained by the additional solid surface brought by the filler particles, which act like sites of nucleation and growth for the hydrates and induce an acceleration of the hydration reactions. Figs. 5 and 6 show that the filler effect is significant since the very first hours of hydration. In addition, during the first $12 \mathrm{~h}$, the increase in limestone filler proportioning from $20 \%$ to $40 \%$ does not cause additional acceleration of the cement hydration. Beyond $12 \mathrm{~h}$ of hydration, the filler effect depends on the cement type. Indeed, it can be observed on Fig. 7 that in the case of CEM 2 cement, the hydration degree at $24 \mathrm{~h}$ of hydration is an increasing linear function of the filler proportioning, whereas for the CEM 1-a cement, the value of hydration degree at $24 \mathrm{~h}$ exhibits a maximum for $\mathrm{LF} / \mathrm{C}=0.25$.

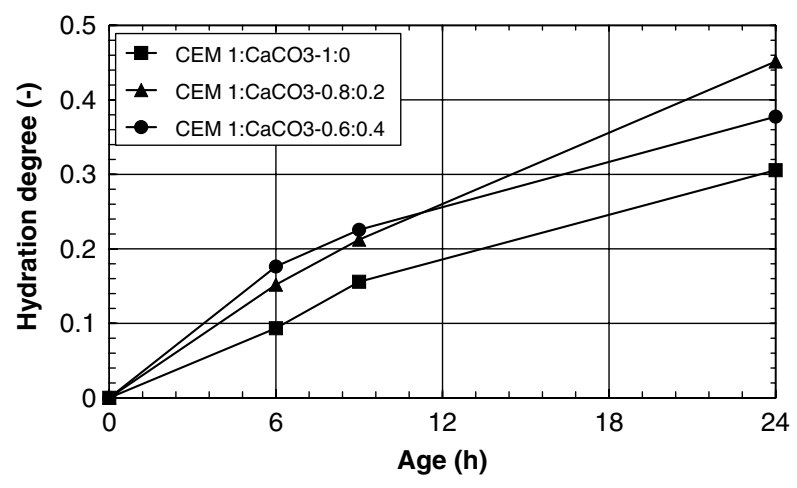

Fig. 5. Hydration degree of CEM 1-a cement pastes $(\mathrm{W} / \mathrm{C}=0.40)$.

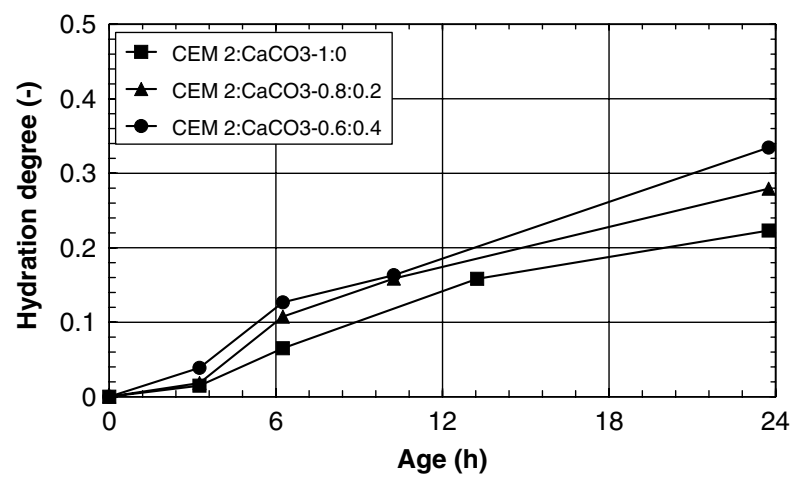

Fig. 6. Hydration degree of CEM 2 cement pastes $(\mathrm{W} / \mathrm{C}=0.40)$. 


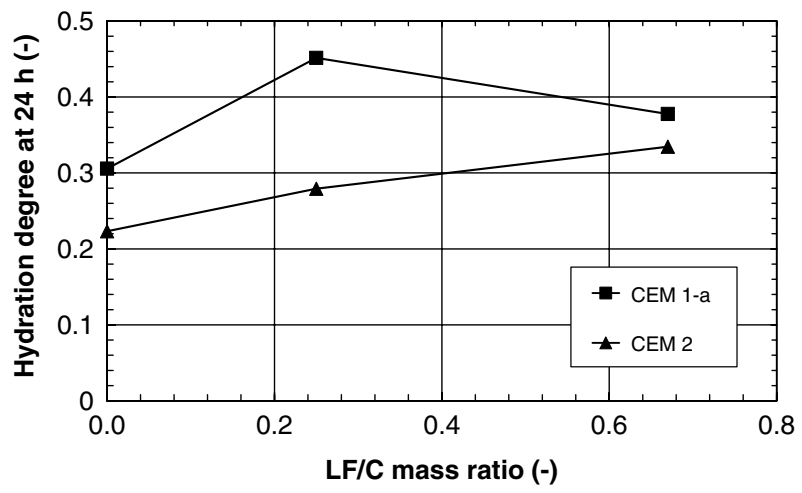

Fig. 7. Hydration degree of cement pastes at $24 \mathrm{~h}$.

Table 7

Results of Vicat setting tests

\begin{tabular}{llll}
\hline Designation & LF/C & $\begin{array}{l}\text { Initial Vicat } \\
\text { setting time }(\mathrm{h})\end{array}$ & $\begin{array}{l}\text { Final Vicat } \\
\text { setting time }(\mathrm{h})\end{array}$ \\
\hline CEM 1:CaCO3-1:0 & 0 & 3.0 & 7.4 \\
CEM 1:CaCO3-0.8:0.2 & 0.25 & 2.3 & 4.8 \\
CEM 1:CaCO3-0.6:0.4 & 0.67 & 1.2 & 3.2 \\
CEM 2:CaCO3-1:0 & 0 & 5.0 & 7.3 \\
CEM 2:CaCO3-0.8:0.2 & 0.25 & 2.5 & 5.0 \\
CEM 2:CaCO3-0.6:0.4 & 0.67 & 1.0 & 3.0
\end{tabular}

\subsubsection{Vicat setting time}

Table 7 displays the results of the Vicat needle tests. For both cement types, the larger the degree of substitution $\mathrm{LF} / \mathrm{C}$, the shorter the final Vicat setting time.

The acceleration of setting is a consequence of the cement hydration rate increase previously observed (section 4.2.1; Figs. 5 and 6). The acceleration of the hydrate production causes a faster percolation of the solid network. It is noted however that the effect of the filler is much more significant on the setting time than on the hydration rate. In fact, it is necessary to keep in mind that the Vicat needle test is a mechanical one, whose result depends largely on the consistency of the cement paste and thus on the water/solid ratio $\mathrm{W} /(\mathrm{LF}+\mathrm{C})$. Indeed, the hydrate volume required to reach the percolation threshold decreases when the water/solid ratio decreases. The reduction of the setting time consecutive to the limestone filler addition should be interpreted as the combined result of the hydration rate increase and the augmentation of the solid fraction.

\subsubsection{Chemical shrinkage}

Figs. 8 and 9 represent the evolution of the chemical shrinkage as a function of the cement paste age up to $24 \mathrm{~h}$ of hydration. The curves are initialized at $1 \mathrm{~h}$ after the first water-cement contact.

For a given age, the chemical shrinkage is higher for the cement pastes containing limestone filler. At least two explanations can be advanced: on the one hand, as the chemical shrinkage is a direct consequence of the hydration

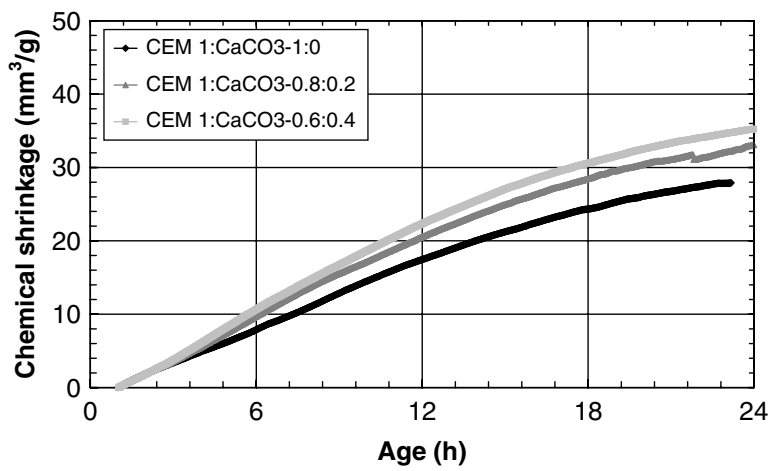

Fig. 8. Chemical shrinkage of CEM 1-a cement pastes $(\mathrm{W} / \mathrm{C}=0.40)$.

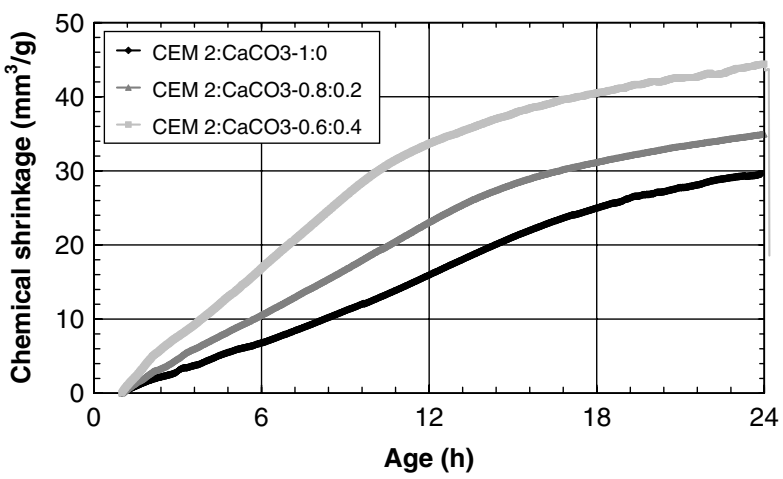

Fig. 9. Chemical shrinkage of CEM 2 cement pastes $(\mathrm{W} / \mathrm{C}=0.40)$.

reactions, the acceleration of the cement hydration due to the presence of the filler induces an increase of the chemical shrinkage rate. In addition, the presence of filler modifies cement hydration products. For example, the monosulfoaluminate $(\mathrm{Afm})$ and the limestone filler react slowly to form monocarboaluminate (Afmc) (see the bibliographical analysis in [9]), which has a higher density than the Afm phase [49].

This latter effect is quantified by representing the chemical shrinkage evolution as a function of cement hydration degree. On Figs. 10 and 11, it can be observed that, for each cement type, there is a quasi-linear relation between

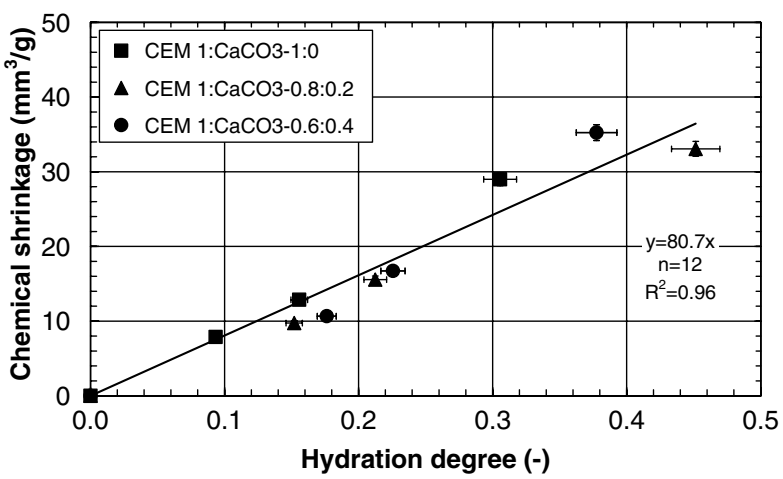

Fig. 10. Chemical shrinkage vs. hydration degree of CEM 1-a cement pastes $(\mathrm{W} / \mathrm{C}=0.40)$. 


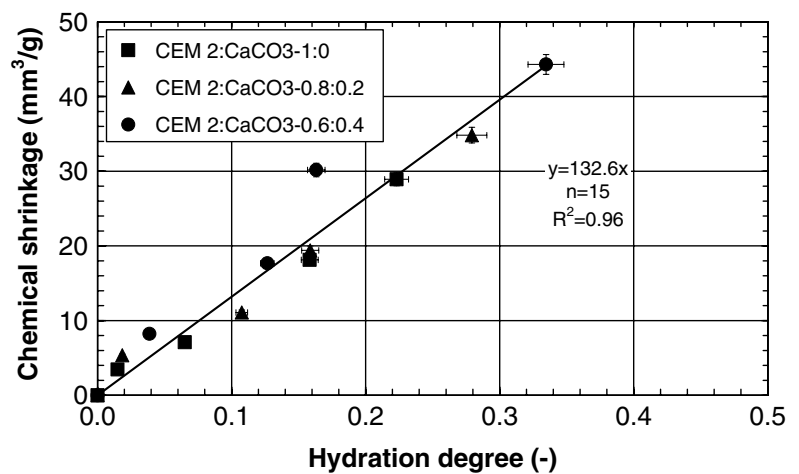

Fig. 11. Chemical shrinkage vs. hydration degree of CEM 2 cement pastes $(\mathrm{W} / \mathrm{C}=0.40)$.

the two parameters, whatever the limestone filler proportioning. This result shows that the filler effect on the cement paste chemical shrinkage can be regarded as a mainly kinetic effect at very early age.

\subsection{Effect of granular inclusions}

The second part of this article is dedicated to the study of the influence of granular inclusions on the rate and the amplitude of the cementitious matrix chemical shrinkage at very early age. The effect of shape, size and concentration of aggregates is investigated. Two aggregate types are used: glass beads with a diameter of $2 \mathrm{~mm}$ and natural river sand filtered to obtain two tightened particle size distributions. Sand denoted " $2 \mathrm{~mm}$ " corresponds to the fraction of aggregates recovered between the sieves 1.6 and $2.5 \mathrm{~mm}$ and sand called " $1 \mathrm{~mm}$ " is the fraction obtained between the sieves 0.8 and $1.25 \mathrm{~mm}$.

\subsubsection{Influence of aggregate shape, concentration and size}

Fig. 12 displays the evolution of chemical shrinkage between 1 and $24 \mathrm{~h}$ for different W/C-ratio mortars (W/ $\mathrm{C}=0.30$ and 0.40 ) prepared with aggregates of different shape (sand and glass beads), size (1 and $2 \mathrm{~mm})$ and with different concentrations $\mathrm{A} / \mathrm{C}(\mathrm{A} / \mathrm{C}=0.5$ and 1$)$.

The curves obtained are almost superimposed up to $8 \mathrm{~h}$ of hydration; beyond, they form a tightened spindle until

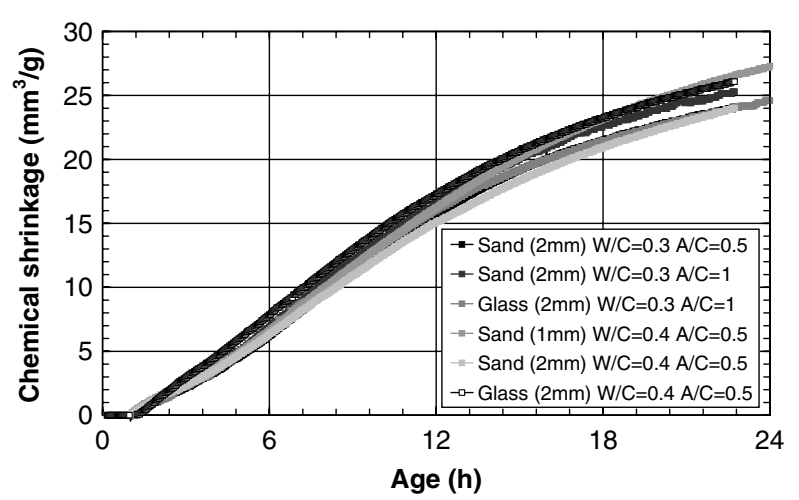

Fig. 12. Effect of aggregate shape. the end of the test. Keeping equal all other parameters, a modification of $\mathrm{W} / \mathrm{C}$ ratio, aggregate concentration or shape causes only weak or very weak variation (lower than $3 \%$ ) of the chemical shrinkage rate of the studied mortars.

At $24 \mathrm{~h}$, the maximum difference, equal to $11 \%$, is observed between the final amplitudes of the curves of mortars prepared with the same $\mathrm{W} / \mathrm{C}$ and $\mathrm{A} / \mathrm{C}$ ratios but with a different aggregate size: these are the curves "Sand $(1 \mathrm{~mm})$ $\mathrm{W} / \mathrm{C}=0.4 \mathrm{~A} / \mathrm{C}=0.5$ " and "Sand $(2 \mathrm{~mm}) \mathrm{W} / \mathrm{C}=0.4$ $\mathrm{A} / \mathrm{C}=0.5$ ". The difference between the two curves can be explained by a more effective mixing in presence of "1 mm" aggregates. Indeed, for a constant granular mass fraction, the finer aggregates are more numerous and their granular specific surface per gram of sample is larger: the number of cement clusters broken by shearing or impact with sand grains is then more important and the cement fraction directly in contact with water increases. It results in higher chemical shrinkage amplitude for the mortar containing " $1 \mathrm{~mm}$ " aggregates.

It should finally be noted that a difference of $11 \%$ also exists between the curves "Sand $(1 \mathrm{~mm}) \mathrm{W} / \mathrm{C}=0.4 \mathrm{~A} /$ $\mathrm{C}=0.5$ " and "Glass $(2 \mathrm{~mm}) \mathrm{W} / \mathrm{C}=0.3 \mathrm{~A} / \mathrm{C}=1 "$, but the simultaneous variation of several mix parameters makes the interpretation of this difference very complex.

\subsubsection{Effect of granular surface area}

In order to specify the aggregate effect on the chemical shrinkage of sand mortars, the chemical shrinkage amplitude reached at $23 \mathrm{~h}$ is represented on Fig. 13 as a function of the granular specific surface area per gram of sample. This specific surface is calculated by assuming the aggregates " $1 \mathrm{~mm}$ " and " $2 \mathrm{~mm}$ " as spheres of radius 0.5 and $1 \mathrm{~mm}$, respectively.

Fig. 13 shows a tendency of the chemical shrinkage amplitude to increase as the developed aggregate surface area grows. The influence of aggregates on Le Chatelier's contraction was already discussed by Holt [34]: she supposes that this effect is mainly due to the improvement of mixing, inducing a better cement cluster destruction, and the formation of a very porous interfacial zone around the aggregates. It should be noted that this double effect

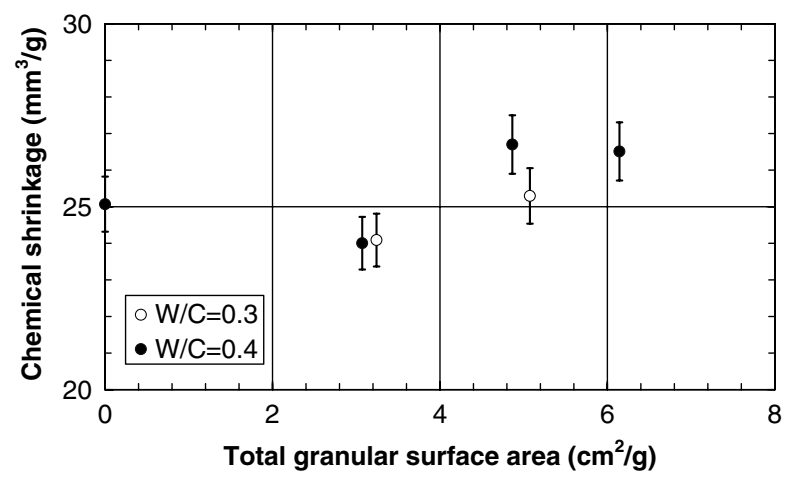

Fig. 13. Effect of granular surface area on chemical shrinkage measured at $23 \mathrm{~h}$ of hydration. 


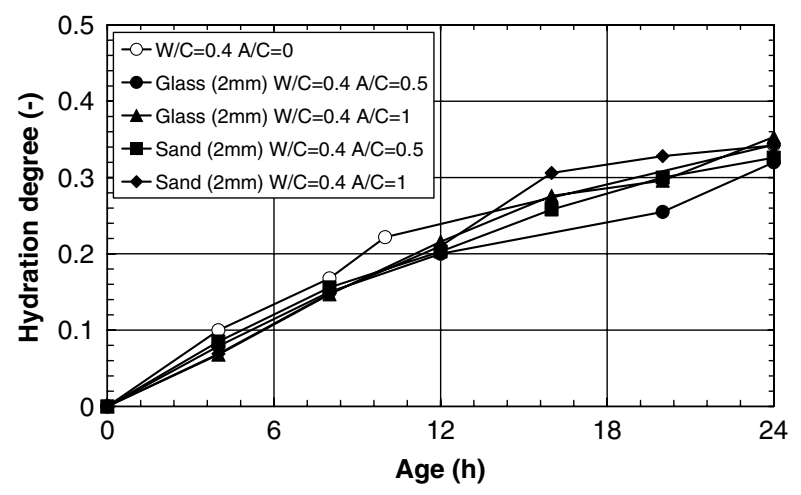

Fig. 14. Hydration degree of cement paste and mortars.

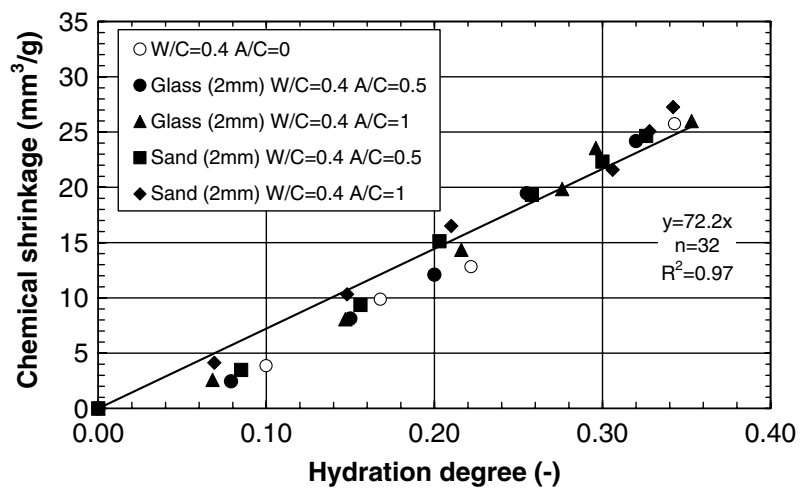

Fig. 15. Chemical shrinkage vs. hydration degree of CEM 1 cement paste and mortars.

remains weak: on Fig. 13, the multiplication by 3 of the specific surface area of aggregates does only cause an increase of $10.5 \%$ of the chemical shrinkage at $23 \mathrm{~h}$ of hydration.

\subsubsection{Chemical shrinkage vs. hydration degree}

The analysis of Figs. 12 and 13 revealed that the presence of aggregates only causes a slight increase of the mortar chemical shrinkage. This result is in accordance with the hydration degree measurements whose results are provided in Fig. 14.

In order to quantify the relation between Le Chatelier's contraction and the degree of hydration of mortars, the evolution of the chemical shrinkage has been plotted as a function of the hydration degree on Fig. 15. It is observed that for the various studied mortars, the amplitude of the chemical shrinkage increases quasi-linearly with the progress of hydration and the slope value of this linear function can be considered as unique for the whole mixtures.

\section{Conclusions}

The results of this study on the influence of limestone filler and granular inclusions on the evolution of chemical shrinkage and hydration degree of cementitious matrices between 0 and $24 \mathrm{~h}$ showed that:

- The presence of limestone filler causes an acceleration of the chemical shrinkage and the hydration process since the very first hours. This filler effect is generally explained by the supplementary surface area provided by the filler particles, playing the role of nucleation sites for hydrates. Consecutively, the Vicat setting time is also accelerated in presence of limestone fillers. The increase of chemical shrinkage and hydration rate depends on the cement type: it is more important for CEM 2 cement than for CEM 1 cement.

- The presence of granular inclusions with diameter between 1 and $2 \mathrm{~mm}$, only has a weak influence on the evolutions of Le Chatelier's contraction and hydration degree of mortars at very early age.

- Limestone fillers and granular inclusions do not cause significant modification of the quasi-linear relation linking the chemical shrinkage to the hydration degree of the cementitious matrices.

This last information is particularly important in the aim of predicting the early age volume changes of cement-based systems: the chemical shrinkage is the first phase of deformation (Fig. 1) and its expression as a function of the hydration degree can be obtained, for a given mortar, directly and with a good approximation from the corresponding W/C-ratio cement paste (Figs. 10, 11 and $15)$.

\section{References}

[1] Bazant ZP, Wittmann FH, editors. Creep and shrinkage in concrete structures. New York: Wiley; 1982.

[2] Mounanga P, Khelidj A, Loukili A, Baroghel-Bouny V. Predicting $\mathrm{Ca}(\mathrm{OH})_{2}$ content and chemical shrinkage of hydrating cement pastes using analytical approach. Cem Concr Res 2004;34(2):255-65.

[3] Chloup-Bondant M, Evrard O. Tricalcium aluminate and silicate hydration. Effect of limestone and calcium sulfate. In: Colombet P, editor. Proceedings of the 2nd international conference on nuclear magnetic resonance spectroscopy of cement-based materials. Berlin: Springer Verlag; 1998. p. 295-308.

[4] Jiang S, Van Damme $\mathrm{H}$. Influence of fillers on textural and mechanical properties of $\mathrm{C}_{3} \mathrm{~S}$ pastes. In: Colombet $\mathrm{P}$, editor. Proceedings of the 2 nd international conference on nuclear magnetic resonance spectroscopy of cement-based materials. Berlin: Springer Verlag; 1998. p. 379-85.

[5] Péra J, Husson S, Guilhot B. Influence of finely ground limestone on cement hydration. Cem Concr Comp 1999;21(2):99-105.

[6] Poppe AM, de Schutter G. Effect of limestone filler on the cement hydration in self-compacting concrete. In: Wallevik O, Nielsson I, editors. Proceedings of the 3rd international RILEM symposium on self-compacting concrete. Reykjavik: RILEM Publications; 2003. p. 558-66.

[7] Tsivilis S, Kakali G, Chaniotakis E, Souvaridou A. A study of the hydration of Portland limestone cement by means of TG. J Therm Anal 1998;52:863-70.

[8] Bonavetti VL, Rahhal VF, Irassar EF. Studies on the carboaluminate formation in limestone filler-blended cements. Cem Concr Res 2001;31(6):853-9. 
[9] Bentz DP. Modelling the influence of limestone filler on cement hydration using CEMHYD 3D. Cem Concr Comp 2006;28(2):124-9.

[10] Zimbelmann R. A contribution to the problem of cement-aggregate bond. Cem Concr Res 1985;15(5):801-8.

[11] Bentz DP, Stutzman PE, Garboczi EJ. Experimental and simulation studies of the interfacial zone in concrete. Cem Concr Res 1992;22(5):891-902.

[12] Ollivier JP, Maso JC, Bourdette B. Interfacial transition zone in concrete. Adv Cem Mater 1995;2(1):30-8.

[13] Turcry P, Loukili A, Haidar K, Pijaudier-Cabot G, Belarbi A. Cracking tendency of self-compacting concrete subjected to restrained shrinkage: experimental study and modelling. J Mater Civ Eng 2006;18(1):46-54.

[14] Knudsen T, Geiker M. Chemical shrinkage as an indicator of the stage of hardening. Proceedings of international conference on concrete at early ages, vol. I. Paris: ENPC Press; 1982. p. 163-5.

[15] Geiker M, Knudsen T. Chemical shrinkage of Portland cement pastes. Cem Concr Res 1982;12(5):603-10.

[16] Geiker M. Measurements of chemical shrinkage and a systematic evaluation of hydration curves by means of the dispersion model. Thèse de Doctorat, Technical University of Denmark; 1983.

[17] Paulini P. A weighing method for cement hydration. In: Mullick AK, editor. Proceedings of the 9th international congress on the chemistry of cement. New Delhi: National Council for Cement and Building Materials; 1992. p. 248-54.

[18] Paulini P. Chemical shrinkage as indicator for hydraulic bond strength. In: Justnes H, editor. Proceedings of the 10th international congress on the chemistry of cement, Göteborg (Sweden); 1997.

[19] Justnes H, Reyniers B, Van Loo D, Sellevold EJ. An evaluation of methods for measuring chemical shrinkage of cementitious paste. Nordic Concr Res 1994;14:45-61.

[20] Justnes H, Van Gemert A, Verboven F, Sellevold EJ. Total and external chemical shrinkage of low W/C ratio cement pastes. Adv Cem Res 1996;8(31):121-6.

[21] Justnes H, Ardouillie B, Hendrix E, Sellevold EJ, Van Gemert D. The chemical shrinkage of pozzolanic reaction products. In: Malhotra $\mathrm{VM}$, editor. Proceedings of the 6th CANMET/ACI/JCI international conference on fly ash, silica fume, slag and natural pozzolan in concrete. Farmington Hills: ACI special publications; 1998. p. 191-205.

[22] Justnes H, Sellevold EJ, Reyniers B, Van Loo D, Van Gemert A, Verboven $\mathrm{F}$, et al. The influence of cement characteristics on chemical shrinkage. In: Tazawa EI, editor. Proceedings of the international workshop on autogenous shrinkage of concrete (Autoshrink'98). Londres: E\&FN Spon; 1999. p. 71-80.

[23] Justnes H, Sellevold EJ, Reyniers B, Van Loo D, Van Gemert A, Verboven F, et al. Chemical shrinkage of cementitious pastes with mineral additives. In: Persson B, Fagerlund G, editors. Proceedings of the 2nd international research seminar on self-desiccation and its importance in concrete technology. Lund: Lund University; 1999. p. 73-84.

[24] Justnes H, Sellevold EJ, Reyniers B, Van Loo D, Van Gemert A, Verboven F, et al. Chemical shrinkage of cement pastes with plasticizing admixtures. Nordic Concr Res 2000;24:39-54.

[25] Justnes H, Clemmens F, Depuydt P, Van Gemert D, Sellevold EJ. Correlating the deviation point between external and total chemical shrinkage with the setting time and other characteristics of hydrating cement paste. In: Baroghel-Bouny V, Aïtcin P, editors. Proceedings RILEM symposium on shrinkage of concrete (Shrinkage 2000). Paris: RILEM Publications; 2000. p. 57-73.

[26] Tazawa EI, Miyazawa S, Kasai T. Chemical shrinkage and autogenous shrinkage of hydrating cement paste. Cem Concr Res 1995;25(2):288-92.

[27] Persson B. Experimental studies of the effect of silica fume on chemical shrinkage and self-desiccation in Portland cement mortars. In: Persson B, Fagerlund G, editors. Proceedings of the 1st international research seminar on self-desiccation and its importance in concrete technology. Lund: Lund University; 1997. p. 116-31.
[28] Wild S, Khatib JM, Roose LJ. Chemical shrinkage and autogenous shrinkage of Portland cement - metakaolin pastes. Adv Cem Res 1998;10(3):109-19.

[29] Hammer T, Heese C. Early age chemical shrinkage and autogenous deformation of cement pastes. In: Persson B, Fagerlund G, editors. Proceedings of the 2nd international research seminar on selfdesiccation and its importance in concrete technology. Lund: Lund University; 1999. p. 7-13.

[30] Boivin S, Acker P, Rigaud S, Clavaud B. Experimental assessment of chemical shrinkage of hydrating cement paste. In: Tazawa EI, editor. Proceedings of the international workshop on autogenous shrinkage of concrete (Autoshrink'98). Londres: E\&FN Spon; 1999. p. 8192.

[31] Garcia Boivin S. Retrait au jeune âge du béton: Développement d'une méthode expérimentale et contribution à l'analyse physique du retrait endogène. PhD thesis, Paris, ENPC; 1999 [in French].

[32] Beltzung F, Wittmann FH. Dissolution of cement and early chemical shrinkage of cement paste. In: Baroghel-Bouny V, Aïtcin P, editors. Proceedings RILEM symposium on shrinkage of concrete (Shrinkage 2000). Paris: RILEM Publications; 2000. p. 91-7.

[33] Holt E. Where did these cracks come from? Conc Int 2000;22(9):57-60

[34] Holt E. Early age autogenous shrinkage of concrete. $\mathrm{PhD}$ thesis, Technical Research Centre of Finland Seattle; 2001.

[35] Holt E. Very early age autogenous shrinkage: governed by chemical shrinkage or self-desiccation? In: Persson B, Fagerlund G, editors. Proceedings of the 3rd international research seminar on selfdesiccation and its importance in concrete technology. Lund: Lund University; 2002. p. 1-25.

[36] Holt E. Contribution of mixture design to chemical and autogenous shrinkage of concrete at early ages. Cem Concr Res 2005;35(3): 464-72.

[37] Charron JP, Marchand J, Bissonnette B, Pigeon M, Zuber B. Comparative study of the effects of water/binder ratio and silica fume on the volume instability of hydrating cement pastes at early-age. In: Persson B, Fagerlund G, editors. Proceedings of the 3rd international research seminar on self-desiccation and its importance in concrete technology. Lund: Lund University; 2002. p. 39-50.

[38] Charron JP, Marchand J, Bissonnette B. Early-age deformations of hydrating cement systems: comparison of linear and volumetric shrinkage measurements. In: Bentur A, editor. Proceedings RILEM of the international conference on early age cracking in cementitious systems (EAC'01). Paris: RILEM publications; 2001. p. 245-57.

[39] Lura P. Autogenous deformation and internal curing of concrete. $\mathrm{PhD}$ thesis. Delft University Press, The Netherlands; 2003.

[40] Bouasker M, Turcry P, Mounanga P, Loukili A. Influence of limestone filler on chemical shrinkage and hydration of cement pastes at early age. In: Pijaudier-Cabot G, Gérard B, Acker P, editors. Proceedings of the 7th international conference on creep, shrinkage and durability of concrete and concrete structures. Paris: Hermès Science Publishing; 2005. p. 559-64.

[41] Bentz DP. CEMHYD3D: A Three-Dimensional Cement Hydration and Microstructure Development Modeling Package. Version 3.0, National Institute of Standards and Technology Interagency Report 7232, Technology Administration, US Department of Commerce, June 2005.

[42] Bouasker M, Grondin F, Mounanga P, Pertué A, Khelidj A. Improved measurement methods for autogenous shrinkage of cement mortars at very early age. In: International conference on advances in concrete through science and engineering, Québec (Canada), 11-13th September 2006

[43] Powers TC. Absorption of water by Portland cement paste during the hardening process. Indus Eng Chem 1935;27(7):790-4.

[44] Buil M. Contribution à l'étude du retrait de la pâte de ciment durcissante. Research report no. 92, Laboratoire Central des Ponts et Chaussées; 1979 [in French].

[45] Japan Concrete Institute Report, Technical committee on autogenous shrinkage of concrete. In: Proceedings of the international workshop 
on autogenous shrinkage of concrete autoshrink '98, Hiroshima (Japon). Londres: E\&FN Spon; 1998. p. 3-62.

[46] Rey M. Nouvelle méthode de mesure de l'hydratation des liants hydrauliques. Publications Techniques du CERILH, no. 31; 1950 [in French].

[47] Knudsen T, Geiker M. Obtaining hydration data by measurement of chemical shrinkage with an archimeter. Cem Concr Res 1985;15(2): $381-2$.
[48] Sant G, Lura P, Weiss J. Measurement of volume change in cementitious materials at early ages: review of testing protocols and interpretation of results. In: 85th Annual meeting of the Transportation Research Board, Washigton (DC); 2006.

[49] Renaudin G, Francois M, Evrard O. Order and disorder in the lamellar hydrated tetracalcium monocarboaluminate compound. Cem Concr Res 1999;29(1):63-9. 